UDC 637.8-021.4:66-911.48:577.114.4

DOI: 10.15587/2706-5448.2021.246560

Article type «Original research»

\section{Tatiana Nikitchina, Tatiana Manoli, Olena Miroshnichenko, Hanna Korkach, Olena Kotuzaki, Svetlana Pambuk}

\title{
FORMATION OF CONSUMER PREFERENCES IN THE FISH RESTAURANTS MENU BASED ON SENSORY CHARACTERISTICS
}

The object of research is fish culinary products in the jelly pouring of the menu of conceptual restaurants. The subject of research is the consumer characteristics of gelling fish broth for culinary products based on sensory characteristics.

The study used methods for determining the consumer characteristics of fish culinary products based on physical, chemical, aesthetic and sensory analysis. Methods for the preliminary preparation of hydrocolloids as structure-forming agents for the preparation of gelling culinary products with the study of the parameters of the jelly formation process are proposed. The developed ingredient composition of fish culinary products based on low methoxylated pectin and sodium alginate improves the consumer characteristics of the finished dish. This ensures the implementation of strategic decisions in the food industry through the introduction of innovative technologies and the release of products with new consumer and functional properties. It is the new ingredient composition of the fish culinary products in the pouring that opens the priorities in the creation of the wellness products industry with the aim of improving the health of consumers. The active elements of algae are absorbed almost completely through a chemical composition close to that of human plasma. As a result, algae are able to compensate for the lack of elements and contribute to the normalization of metabolism. The use of low-esterified pectin is due to its structure-forming, therapeutic and prophylactic, sorption, antibacterial properties, which are an alternative to antibiotics and synthetic preservatives to prevent bacterial spoilage. The use of dietary supplements based on sodium alginate and pectin in food products provide an adjustable texture with new rheological and functional properties, which have a positive effect on the commodity performance of finished products for promotion on the market of healthy food restaurants.

On the basis of the sensory indicator, rational parameters of the recipe of fish culinary products in jelly pouring were determined to obtain a transparent, stable, homogeneous elastic consistency, which will expand the range of the wellness menu of restaurants of the Wellness concept.

Keywords: consumer characteristics, sensory indicators, jelly culinary products, structure-forming agents, fish restaurants.

\section{How to cite}

Nikitchina, T., Manoli, T., Miroshnichenko, O., Korkach, H., Kotuzaki, O., Pambuk, S. (2021). Formation of consumer preferences in the fish restaurants menu based on sensory characteristics. Technology Audit and Production Reserves, 6 (3 (62)), 33-38. doi: http://doi.org/10.15587/2706-5448.2021.246560

\section{Introduction}

Nowadays, a healthy lifestyle (HLS) and an approach to its standards are gaining more and more popularity in the world, which is reflected in the fashion for personality development, maintaining physical fitness, and healthy eating. Let's consider this issue on the example of Ukraine, for which a healthy lifestyle is also relevant, and therefore more and more proposals for attracting investments in these areas appear in the hotel and restaurant business [1-3]. The modern lifestyle and external factors: ecology, economic instability, psychological atmosphere does not contribute to maintaining a healthy lifestyle both among the population of Ukraine and around the world, which is becoming a global problem today. Therefore, one of the important tasks of modern society was the development of concepts aimed at improving the quality of life and human health. This problem has been repeatedly solved by well-known world scientists. So, the principles of healthy lifestyle were first introduced into practice by the American physician H. L. Dunn in 1959. These principles included a healthy and beautiful body, mental alertness, healthy eating, and psychological harmony. This approach to human health has become the basis of the world famous concept of Wellness (from English bewell to be in good health). The main task of the Wellness concept: due to proper healthy nutrition, mental and physical stress, to prevent negative impact on a person, as a result of which the world community will come to the «healthier» of the nation $[4,5]$. 
The restaurant business has a highly competitive atmosphere. The peculiarity and uniqueness of the interior, conceptuality, and menu contribute to the increase in the competitiveness of restaurant facilities. According to The International Life Sciences Institute [6], consumers view food as a way to improve their health, and the restaurant industry is responding quickly with new dishes to meet this demand. Expanding the range of restaurant dishes through the formation of a healthy food menu contributes to expanding the client base and increasing competitiveness. When laying the concept for the development of restaurant establishments on the basis of the unstable economic state of recent years, the approaches to the formation of the assortment menu are being revised. Fish restaurants are especially popular in the Odesa region (Ukraine), which emphasize the advertising of their establishments on regional and health products from aquatic organisms. One of the interesting and promising assortment directions of the menu can be gourmet fish products in jelly pouring based on uronid polysaccharides. Culinary products in jelly pourings are traditional mass consumption dishes as a decoration of the festive table [7].

When choosing a dish, organoleptic indicators are a determining factor in the competitiveness and safety of products, since they characterize compliance with consumer requirements. Survey results showed that consumers prefer to rate the level of food safety in a restaurant based on «sensory perception of food» and «restaurant environment» [8].

An objective assessment of the sensory performance of new foods can be presented using a descriptive expert profile analysis method. The FlavorProfil profile analysis method is the only official and best known of the sensory test methods [6,9]. It is based on the fact that separate gustatory, olfactory and other stimuli, when combined, give a qualitatively new definition of the deliciousness of the product. Isolation of the most characteristic flavor elements for this product allows to establish the flavor profile, as well as to study the influence of various factors (technological modes, storage conditions, the composition of raw materials, etc.) on its taste.

Fish as a food product has exceptionally high nutritional qualities, therefore it occupies an important place in human nutrition. It is an ideal raw material for the production of health food, as it contains complete proteins, essential fatty acids, including the unique eicosapentaenoic and docosahexaenoic, fat-soluble vitamins, micro- and macroelements in favorable ratios for the body.

The classic development of the production of fish culinary products is based on the basis of fish broths with the use of gelatin. For the formation of ears on the basis of only fish broth, it is necessary to achieve a mass fraction of dry matter of at least $12 \%$. These fish broths also have a low melting point of $14{ }^{\circ} \mathrm{C}$. At the same time, the gel is very soft and loose. The use of a composition of fish broth with gelatin makes it possible to increase the melting temperature to $22-24{ }^{\circ} \mathrm{C}$ and obtain a soft elastic gel [10]. For the formation of such a jelly, the mass fraction of gelatin must be at least $4 \%$. The complexity of the preparation of fish broth and the high consumption of gelatin are the main problems of the technology of fish culinary products with high consumer properties. Therefore, it is relevant to study fish culinary products in jelly pouring for the menu of conceptual restaurants and develop consumer characteristics of the product based on sensory characteristics.

\section{The object of research and its technological audit}

The object of research is fish culinary products in the jelly pouring of the menu of conceptual restaurants. The subject of the research is the consumer characteristics of fish broth for culinary products based on sensory characteristics.

One of the most problematic places is getting fish culinary products in jelly pourings. For the research, let's use low-esterified pectin with a degree of esterification of $28-35 \%$ from the juice production waste of fruit-processing enterprises in the Odesa region. The technology for obtaining low-esterified pectin differs from the classical one due to the use of bio-methods based on enzymes of plant raw materials without the use of aggressive chemicals. This technology makes it possible to obtain environmentally friendly food bioactive additives, which popularizes their use in Wellness products in restaurants offering healthy food to consumers [11].

The use of only low methoxylated pectin makes it possible to obtain delicate but unstable dredge. To strengthen the jelly structure, to improve the structural and mechanical properties of the consistency, up to $2.0 \%$ sodium alginate of the Danisco FD 127 brand (Denmark) was introduced into the test sample [12].

The formation of a jelly pouring based on sodium alginate and low-esterified pectin substances is subject to a chemical ion-exchange reaction. Therefore, to enhance the jelly-forming and sorption properties, calcium ions were added, which were introduced in the form of an $8.5-10 \%$ solution of calcium chloride according to TU 21.2-25657043-069-2014.

Getting a jelly pouring occurs in stages:

- formation of a mixture of structure-forming agents with the addition of strength and sugar according to taste indicators;

- adding a spicy broth with an exposure in the range of 10-40 minutes for swelling of hydrocolloids;

- mix thoroughly to obtain a jelly pouring with evenly dissolved ingredients.

\section{The aim and objectives of research}

The aim of research is to study consumer and sensory characteristics of fish culinary products in jelly pourings of structure-forming agents obtained from waste of vegetable raw materials processing. To achieve this aim, the following objectives must be completed:

1. Determine the parameters of the preliminary preparation of hydrocolloids to obtain a jelly pouring.

2. Investigate the influence of technological parameters on consumer and sensory characteristics of a jelly.

3. Obtain a jelly pouring with a stable dredge for culinary fish products of healthy nutrition in compliance with the requirements for commodity indicators based on profilograms of a complex of sensory characteristics.

\section{Research of existing solutions to the problem}

Traditionally, fish broths with gelatin are most often used in the technology for the production of fish culinary products. The energy intensity of the preparation of fish broth and the significant consumption of gelatin are the main problems of the technology of fish culinary products. 
Such culinary products have a short-term shelf life of up to 96 hours, which is associated with the protein nature of the gelling agent and the presence of free amino acids [13].

Another problem when receiving a pouring based on fish broth is a mandatory technological operation - lighting. To obtain a transparent, attractive pouring, egg whites are used, which require additional equipment and special methods when working with egg products [14].

Fish culinary products obtained by traditional technology in jelly pourings with a high content of extractive substances cannot be classified as healthy nutrition, since they increase the load on the liver and kidneys, which limits their use in the assortment of dishes of the Wellness concept [5].

The imperfection of the classical technology leads to the creation of new methods with the use of structureforming agents, which are not characteristic of culinary fish jelly products, but which impart functional and preventive properties to the finished product. Sodium alginate (AlgNa) obtained by alkaline extraction of brown algae and pectin substances, the main source of which are fruits and vegetables, is such structure-forming agents that improve the consumer properties of food products. Sodium alginate has well-known therapeutic and prophylactic properties, which led to its widespread use in medicine, biotechnology, and various branches of the food industry [15].

In the formation of the merchandising properties of jelly fish dishes, an important role is assigned to the rheological properties of the structure-forming agents.

The formation of a jelly structure in the zones of ionotropic gelation in alginate solutions occurs with the participation of ions of divalent metals through the interaction of molecules with each other [15]. The jelly formation of alginates is influenced by the concentration of alginate, its chemical composition and molecular weight; the ratio between the substances participating in the jelly formation process. The speed of the process and the irreversibility of the binding reaction between cations and alginates are a significant drawback in the technology for the production of jelly based on alginates.

The main purpose of plant-based structure-formers in food technology is to obtain a structure with controlled rheological parameters. The jelly formation of low esterified pectin substances (LPS) is based on the interaction between pectin and calcium ions [16].

A promising trend in the new concept of the modern restaurant industry is the development of fish products in jellyshaped pouring with syneresis-resistant properties [16, 17]. These properties of pourings are largely influenced by the nature of the structure-forming agents, which impart certain structural and mechanical properties to the dredge. Therefore, the development of substantiated technological parameters of fish culinary products using natural structure-forming agents of plant origin, providing high merchandising properties, is promising. However, there are technological imperfections in the production of such products, which include obtaining controlled elastic-plastic properties of the pouring during jelly formation and preventing syneresis during refrigerated storage. This problem was studied in the study of the influence of the type and concentration of food ingredients of a polysaccharide nature on crystallization processes and the stability of systems during deep refrigeration [18].

When solving problematic technological problems in order to obtain new and improved rheological properties of jelly pourings for fish culinary products, it is interesting to use a mixture of hydrocoloids of vegetable nature [11].
The works of many researchers were devoted to the expansion of the functional and technological properties of hydrocolloids based on the study of associative interactions in the systems of structure-forming agents [19, 20]. The best known experiments are with the addition of a mixture of locust bean gum and kappa-carrageenan to obtain softer transparent gels and locust bean gum taxanthan gum to accelerate the jelly formation process [16, 17].

The potential of food products in jelly pourings from fish raw materials of inland water bodies and seafood, which contain structure-forming agents of plant origin with controlled gelation, for the technological, physiological and economic efficiency of their use has not been disclosed.

Thus, the results of the analysis allow to conclude that the prospect of research lies in the study of the consumer properties of jelly pouring based on a mixture of structureforming agents from plant raw materials, namely pectins with a low degree of esterification and sodium alginate. Such a composition will make it possible to obtain decrepit ones with structural and mechanical properties that are technologically different from pure pectin and alginate gels. The investigated problem will make it possible to develop a wide range of fish culinary products based on the indicated polysaccharides with improved organoleptic characteristics.

\section{Methods of research}

Physicochemical and organoleptic methods were used to solve the set tasks. The consumer properties of the jelly pouring were determined using a Brookfield LV DV-II+Pro rotational viscometer Brookfield (USA). In the flash, the measuring spindle was lowered and the indicators were noted on the calibration coil spring, which were used to calculate the dynamic viscosity using the two constants specified for the spindle.

An important commodity characteristic is the dredge strength, which was determined using a modified Valenta device (Russia) in accordance with GOST 26185-84 at a temperature of $20^{\circ} \mathrm{C}$, the measurement of which provides for the determination of the mass of sand required to destroy the dredge. The prototypes were placed on the working table of the device and set in motion at an idle speed until the jelly surface of the pouring and the spherical nozzle of the Valenta device touched.

Sensory analysis of culinary products was carried out in accordance with international standards DSTU ISO 6564:2005, identifying the main properties that are important in creating an overall impression, in order to be able to describe the sensory characteristics of the product. Revealing consumer preferences was carried out by means of questioning the target category of consumers.

\section{Research results}

It has been found that ensuring stable structural and mechanical properties of dredge during refrigerated storage provides a ratio of 1 particle of low methoxylated pectin and 1 particle of alginic acid with a mass fraction of both structurants of at least $1.5 \%$. The resulting fill has a jelly strength of $112 \mathrm{~g}$ [7] and certain ratios ensure the absence of synergistic changes. Such strength of jelly corresponds to the high merchandising properties of the finished product.

The high viscosity of alginate solutions and high jellyforming properties [12] are based on the chemical structure 
of the sodium alginate molecule. It consists of the residues of D-manuronic and L-guluronic acids, which have a polymeric structure, which promotes solvation in water and dissociation into sodium cations and alginic acid anions

A characteristic property of alginate dredges is a high dissolution temperature of up to $95{ }^{\circ} \mathrm{C}$, which does not affect its viscosity, but is not effective in economic terms and increases the cost of production based on it. The best swelling effect for alginates occurs when the ratio of sodium alginate: water $=1: 8$, with a process time of $55 \pm 5 \min$ [15].

The use of a dry mixture of hydrocoloids when swelling can lead to sticking, the formation of lumps with longterm solubility. To ensure complete dispersion of the dry pectin powder particles, the mixture was mixed with salt and sugar. The complete dissolution process took place during the swelling process at a hydromodule of 1:10 \pm 5 . Increasing the hydronic modulus above 1:10 does not lead to tangible changes.

The pre-swelling solubility is influenced by the degree and rate of swelling. The kinetics of swelling of hydrocolloids was studied by the gravimetric method. The jelly formation parameters for determining the consumer properties of fish culinary products are presented in Table 1.

Tahle 1

Jelly-forming parameters for determining the consumer properties of fish culinary products

\begin{tabular}{|c|c|c|c|c|}
\hline \multirow{2}{*}{$\begin{array}{c}\text { Pracess } \\
\text { time, h }\end{array}$} & \multicolumn{5}{|c|}{ Swelling degree, $\varphi$ \% } \\
\cline { 2 - 5 } & LP5+AlgNa+salt+sugar+10 \% CaCl & LP5 & AlgNa & LP5+AlgNa \\
\hline 0 & 2.8 & 0.2 & 0.3 & 0.3 \\
\hline 15 & 5.9 & 2.7 & 3.1 & 4 \\
\hline 30 & 6 & 3 & 3.8 & 4.4 \\
\hline 45 & 6.2 & 3.1 & 3.9 & 4.5 \\
\hline 60 & 6.2 & 3.1 & 3.9 & 4.5 \\
\hline
\end{tabular}

Experimental data indicate that intense swelling of the developed jelly pouring composition occurs in the first 10 minutes. Upon reaching the swelling degree of $5.8 \%$, the swelling rate slows down. Subsequent studies have shown that an increase in the swelling time does not affect this process and the degree of swelling remains in the range of $5.8-6.2 \%$.

In the production of jelly pourings using structureforming agents sodium alginate and low-esterified pectin substances, it is taken into account how chemical reactions occur during the jelly formation. Since the use of such hydrocolloids leads to ionotropic adhesion, the choice of ingredients involved in the jelly-forming process is therefore important. The use of LPS in the formation of jelly occurs under the condition of the presence of calcium ions; therefore, a $10 \%$ solution of calcium chloride was used as a source. From a literary source [16] it is known that ionotropic adhesion in a mixture of structure-forming agents with LPS, sodium alginate and calcium ions has a different flow rate and requires constant monitoring to obtain dredges with certain rheological properties. To achieve a controlled process, a pre-prepared mixture of the studied structure-forming agents is poured with a spicy broth [7] and heated. Heating prevents premature jelly formation by maintaining thermal movement of the polymer units and preventing the compound from reacting with calcium ions. Further cooling leads to a decrease in the thermal energy of the polymers, and then jelly formation occurs. Calcium ions in the form of a $10 \%$ solution of calcium chloride were added to the mixture of hydrocolloids with a temperature of no more than $60{ }^{\circ} \mathrm{C}$. Experimental samples of jelly pouring were used to determine the effect of the mass fraction of a $10 \%$ solution of calcium chloride in the range of $0.1-0.5 \%$ on the merchandising characteristics of jelly from LPS and sodium alginate.

It has been found that at least $0.3-0.4 \%$ of a $10 \%$ solution of calcium chloride provides a transparent, stable, homogeneous, elastic, elastic consistency of dredge from a mixture of LPS and sodium alginate. With an amount of up to $0.29 \%$ of a $10 \%$ solution of calcium chloride, jelly with synergic properties is formed, with a loose, nonelastic consistency. An increase in the mass fraction of a $10 \%$ calcium chloride solution to 0.45 and more promotes the jelly formation with a dense, rubbery consistency that is prone to brittleness.

It has been established that the mass fraction of a mixture of sodium alginate: LPS - $1.8 \%$ provides a dynamic viscosity of less than $0.94 \mathrm{~Pa} \cdot \mathrm{s}$, which gives gentle and strong, stable dispersions during transportation and packaging of jelly pourings.

It has been determined that the jelly strength of a structure-forming mixture of hydrocolloids depends on the mass fraction of each of them. The increase in the strength of the investigated jelly grows nonlinearly, therefore, the obtained data are unique, and additional experimental studies are required when the jelly pouring formulation changes.

Stable gels were obtained with a strength of more than $110 \mathrm{~g}$, which increases with the introduction of no more than $0.45-0.5 \% 10 \%$ calcium chloride solution into the mixture of hydrocolloids. Analysis of the experimental data of the prototypes indicates that the formation of a stable ear is provided by the mass fraction of the structureforming mixture of hydrocolloids of $1.6-1.8 \%$.

The peculiarity of the obtained jelly pourings according to the developed technology is a high melting point, which is not less than $26{ }^{\circ} \mathrm{C}$, which is an important indicator in the technology of culinary products from aquatic organisms [7] and a promising direction in the development of jelly products from fish raw materials and seafood.

The tasting was conducted by an expert commission of seven people (selected from among the respondents who took part in determining consumer preferences for culinary products from fish in jelly pourings). At the same time, five descriptors were evaluated that were significant for consumers and were included in the complex flavor profile.

Tasting assessment of samples of culinary products from fish in jelly pourings was carried out on a 5-point scale of desirability and intensity of sensation of aromatic and taste properties of the product using the consensus method:

0 - disgusting;

1 -very bad;

2 - bad;

3 - neutral

4 - good;

5 - excellent

Based on the results of tasting, after mathematical processing, a panel of descriptors and a profilogram of the flavor of a hypothetical standard of fish in a jelly pouring were compiled (Table 2). 
Table 2

Flavor profile analysis of fish culinary products in jelly pourings

\begin{tabular}{|c|c|c|}
\hline \multirow{2}{*}{ Descriptor } & \multicolumn{2}{|c|}{ Experimental sample } \\
\cline { 2 - 3 } & $\begin{array}{c}\text { Experimental } \\
\text { sample }\end{array}$ & $\begin{array}{c}\text { Experimental } \\
\text { sample }\end{array}$ \\
\hline Pouring appearance & 5 & 4 \\
\hline Pouring taste & 5 & 5 \\
\hline Smell of pouring & 5 & 4 \\
\hline Fish consistency & 5 & 5 \\
\hline The color of the fish in the break & 5 & 5 \\
\hline
\end{tabular}

As can be seen from the data presented, an experimental sample of a culinary product made from fish in a jelly pouring is characterized by high indicators of the taste of the pouring, consistency and color of fish and has a 1 point lower score in terms of the appearance and smell of the pouring.

For visual perception of the results, the sensory feature of fish culinary products is shown in Fig. 1 in the form of profilograms of a complex of organoleptic indicators of an experimental sample.

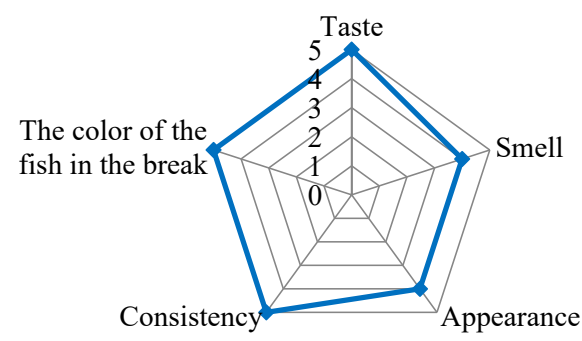

Fig. 1. Sensory characteristics based on complex organoleptic characteristics of fish culinary products

According to the calculations, the area of the experimental sample is 82.2 and the degree of approximation of the flavor profile to ethanol is 0.822 , which corresponds to the expectations of the target category of consumers.

The presented profilogram shows that the organoleptic properties of the finished product reach their maximum in taste, color and consistency, which are the main quality indicators of culinary dishes in jelly pouring.

\section{SWOT analysis of research results}

Strengths. The strengths of this study lie in the fact that the development of the direction of healthy eating is proposed for the introduction of a specialized assortment to promote an innovative approach in the development of the modern restaurant food industry.

Weaknesses. The weaknesses of this study are associated with the use of a natural structure-forming agent - pectin substances, which today are an exported ingredient due to the lack of an industrial Ukrainian analogue.

Opportunities. Additional opportunities when using the above results in the restaurant industry are the improvement of the menu due to fish culinary products in jelly pouring with the use of natural structure-formers, which can become the basis for an innovative project to create a health menu or expand concept restaurants.
Threats. The developments proposed in this work are of a practical nature, but require a socio-economic justification for the formation of the main strategic priorities for the development of conceptual Wellness restaurants.

\section{Conclusions}

1. To obtain stable consumer properties of ears during refrigerated storage, the ratio of structure-forming agents is determined: 1 share of low-methoxylated pectin and 1 share of alginic acid with a mass fraction of both structure-forming agents not less than $1.5 \%$

2. Investigation of the swelling process of dry structureforming agents shows that the complete process of their dissolution occurred in the swelling process at a hydromodule of $1: 10 \pm 5$.

3. It is found that not less than $0.3-0.4 \%$ of a $10 \%$ solution of calcium chloride provides a transparent, stable, homogeneous, elastic, elastic consistency of jelly from a mixture of LPS and sodium alginate.

The sensory characteristics of fish culinary products based on profilograms of a complex of organoleptic indicators made it possible to determine high taste characteristics, good color and consistency of the product, which were rated at 5 points on a five-point profilogram scale, which will satisfy the needs of consumer expectations.

\section{References}

1. Khrystova, T. Ye. (2018). Priorytet zdorovoho sposobu zhyttia studentiv. Ekolohiia - filosofiia isnuvannia liudstva, 131-135.

2. Goodyear, V. A., Kerner, C., Quennerstedt, M. (2017). Young people's uses of wearable healthy lifestyle technologies; surveillance, self-surveillance and resistance. Sport, Education and Society, 24 (3), 212-225. doi: http://doi.org/10.1080/13573322.2017.1375907

3. Sansone, F., Mencherini, T., Picerno, P., Lauro, M. R., Cerrato, M., Aquino, R. P. (2019). Development of Health Products from Natural Sources. Current Medicinal Chemistry, 26 (24), 4606-4630. doi: http://doi.org/10.2174/0929867325666180926152139

4. Küster-Boluda, I., Vidal-Capilla, I. (2017). Consumer attitudes in the election of functional foods. Spanish Journal of Marketing ESIC, 21, 65-79. doi: https://doi.org/10.1016/j.sjme.2017.05.002

5. Sidorova, I. G. (2019). Kontseptsiia Wellness v meditsinskom diskurse (na materiale russkoiazychnykh i angloiazychnykh tekstov internet-saitov o zdorovom obraze zhizni). K 63 Коттиnikativnye strategii i lingvokognitionye mekhanizmy porozhdeniia professionalnogo diskursa. Irkutsk: IGMU, 137-146.

6. Ashwell, M. (2004). Concepts of functional food. Nutrition $\&$ Food Science, 34 (1), 47. doi: https://doi.org/10.1108/nfs.2004.34.1.47.3

7. Barysheva, Y., Glushkov, O., Manoli, T., Nikitchina, T., Bezusov, A. (2017). Substantiation of hot smoking parameters based on sensory researches in hot fish marinades technology in the jelly pouring. EUREKA: Life Sciences, 5, 33-38. doi: https:// doi.org/10.21303/2504-5695.2017.00420

8. Bai, L., Wang, M., Yang, Y., Gong, S. (2019). Food safety in restaurants: The consumer perspective. International Journal of Hospitality Management, 77, 139-146. doi: https://doi.org/10.1016/ j.ijhm.2018.06.023

9. Chugunova, O. V., Zavorokhina, N. V. (2010). Ispolzovanie metodov degustatsionnogo analiza pri modelirovanii retseptur pischevykh produktov s zadannymi potrebitelskimi svoistvami. Ekaterinburg: Izd-vo Ural. gos. ekon. un-ta, 148.

10. Parkhutova, I. I. (2010). Nauchno-eksperimentalnoe obosnovanie is-polzovaniia strukturoreguliruiuschikh kompozitsii pri proizvodstve rybnykh kulinarnykh izdelii $\mathrm{v}$ termostoikikh geleobrazuiuschikh zalivkakh. Izvestiia TINRO, 163, 414-429.

11. Nikitchina, T. I., Manoli, T. A., Barysheva, Ia. O. (2015). Development of antihunt systems of sauces in the technology of fish products. Eastern-European Journal of Enterprise Technologies, 2 (10 (74)), 19-24. doi: http://doi.org/10.15587/ 1729-4061.2015.39801 
12. Cao, L., Lu, W., Mata, A., Nishinari, K., Fang, Y. (2020). Eggbox model-based gelation of alginate and pectin: A review. Carbohydrate Polymers, 242, 116389. doi: https://doi.org/10.1016/ j.carbpol.2020.116389

13. Zavadlav, S., Blažić, M., Van de Velde, F., Vignatti, C., Fenoglio, C., Piagentini, A. M. et. al. (2020). Sous-Vide as a Technique for Preparing Healthy and High-Quality Vegetable and Seafood Products. Foods, 9 (11), 1537. doi: https://doi.org/10.3390/ foods9111537

14. Zhang, H., Zhang, F., Yuan, R. (2020). Applications of natural polymer-based hydrogels in the food industry. Hydrogels Based on Natural Polymers. Elsevier, 357-410. doi: https:// doi.org/10.1016/b978-0-12-816421-1.00015-x

15. Hilbig, J., Hartlieb, K., Gibis, M., Herrmann, K., Weiss, J. (2020). Rheological and mechanical properties of alginate gels and films containing different chelators. Food Hydrocolloids, 101, 105487. doi: https://doi.org/10.1016/j.foodhyd. 2019.105487

16. Williams, P. A., Phillips, G. O. (2009). Introduction to food hydrocolloids. Handbook of Hydrocolloids. Woodhead Publishing Limited, 1-22. doi: https://doi.org/10.1533/9781845695873.1

17. Maeda, H., Nakamura, A. (2021). Soluble soybean polysaccharide. Handbook of Hydrocolloids. Elsevier, 463-480. doi: https://doi.org/10.1016/b978-0-12-820104-6.00025-5

18. Presentato, A., Scurria, A., Albanese, L., Lino, C., Sciortino, M., Pagliaro, M. et. al. (2020). Superior Antibacterial Activity of Integral Lemon Pectin Extracted via Hydrodynamic Cavitation. ChemistryOpen, 9 (5), 628-630. doi: https://doi.org/10.1002/ open.202000076

19. Ciriminna, R., Meneguzzo, F., Delisi, R., Pagliaro, M. (2017). Olive Biophenols as New Antioxidant Additives in Food and Beverage. ChemistrySelect, 2 (4), 1360-1365. doi: https://doi.org/ 10.1002 slct.201601900
20. Saha, D., Bhattacharya, S. (2010). Hydrocolloids as thickening and gelling agents in food: a critical review. Journal of Food Science and Technology, 47 (6), 587-597. doi: https:// doi.org/10.1007/s13197-010-0162-6

$\triangle$ Tatiana Nikitchina, PhD, Associate Professor, Department of Hotel and Catering Business, Odessa National Technical University, Odessa, Ukraine, e-mail: nikitchinati@ukr.net, ORCID: http://orcid.org/ 0000-0002-1034-3483

Tatiana Manoli, PhD, Associate Professor, Department of Meat, Fish and Seafood Technology, Odessa National Technical University, Odessa, Ukraine, ORCID: http://orcid.org/0000-0001-9121-9232

Olena Miroshnichenko, PhD, Associate Professor, Department of Wine Technology and Sensory Analysis, Odessa National Technical University, Odessa, Ukraine, ORCID: https://orcid.org/0000-00027701-2056

Hanna Korkach, Doctor of Technical Sciences, Associate Professor, Department of Bread, Confectionery, Macaroni Products and Food Concentrates Technology, Odessa National Technical University, Odessa, Ukraine, ORCID: https://orcid.org/0000-0002-9147-5508

Olena Kotuzaki, PhD, Associate Professor, Department of Bread, Confectionery, Macaroni Products and Food Concentrates Technology. Odessa National Technical University, Odessa, Ukraine, ORCID: http:// orcid.org/0000-0001-9846-8995

Svetlana Pambuk, PhD, Associate Professor, Department of Marketing, Business and Trade, Odessa National Technical University, Odessa, Ukraine, ORCID: https://orcid.org/0000-0002-6651-5774

$\triangle$ Corresponding author 